\title{
Antimutagenic and DNA Damage Protective Activities of a Grape Extract from Vitis vinifera
}

\author{
Zuzana Rybková*, Kateřina Malachová*, Jiří Červeň, Hana Sezimová, Petr Pečinka \\ Institute of Environmental Technologies, Department of Biology and Ecology, Faculty of Science, University of \\ Ostrava, Ostrava, Czech Republic \\ Email: "zuzana.rybkova@osu.cz, "katerina.malachova@osu.cz
}

Received 7 April 2016; accepted 19 May 2016; accepted 24 May 2016

\begin{abstract}
Antimutagenic and DNA protective effect of an extract VinOserae from Vitis vinifera grapes on oxidative DNA damage was investigated. The extract's ability to inhibit mutagenicity induced by tert-butyl hydroperoxide ( $t$-BHP) and hydrogen peroxide $\left(\mathrm{H}_{2} \mathrm{O}_{2}\right)$ was determined with Ames test using Salmonella typhimurium His ${ }^{-}$TA102 strain. Inhibition values of $44.2 \%$ and $67.0 \%$ were detected for $t$-BHP and $\mathrm{H}_{2} \mathrm{O}_{2}$, respectively. A protective ability of the extract against DNA strand scission induced by hydroxyl radicals was studied with plasmid pBluescript II SK(-). The analysis of DNA strand breaks in plasmid DNA showed a significant inhibition of DNA damage.
\end{abstract}

\section{Keywords}

Ames Test, Antimutagenicity, Free Radical Scavenging, DNA Strand Scission, Vitis vinifera

\section{Introduction}

Plants have long been considered as a valuable source of compounds beneficial for humans. Many compounds that are found in plants exhibit a biological activity such as antimicrobial, antioxidative, antiviral, antiinflammatory, antimutagenic and anticarcinogenic [1]-[5]. Polyphenolics in medicinal and fragrant plants, fruit and vegetables belong to such compounds. Their broad protective effect consists in a number of individual complementary actions contributing to the upbuilding and maintenance of homeostasis.

These compounds can help prevent harmful consequences of oxidative damage to biomolecules due to their biological activity and their action play important roles in prevention of various diseases such as cancer or cardiovascular and neurodegenerative diseases [6]-[9]. The antioxidative activity of polyphenolic compounds is given by the ability to bind reactive forms of oxygen and transition metal ions that catalyze formation of free radicals and, also, to inhibit enzymes involved in formation of free radicals [10]-[14].

Vitis vinifera L. is a species of Vitis, its production is widespread throughout the world for fresh consumption and industrial processing [15]. This plant has been used for the production of food and beverage as well as a re-

${ }^{*}$ Corresponding author.

How to cite this paper: Rybková, Z., Malachová, K., Červeň, J., Sezimová, H. and Pečinka, P. (2016) Antimutagenic and DNA Damage Protective Activities of a Grape Extract from Vitis vinifera. Journal of Biosciences and Medicines, 4, 1-8. 
medy against various complaints in traditional medicine [16]. The varied chemical composition of Vitis vinifera grapes appears to contribute to their biological potential. The grapes are rich in polyphenolic compounds such as anthocyanins, flavanols, flavonols, proanthocyanidins, stilbenes (resveratrol), and phenolic acids [17]-[23]. The VinOserae extract contains phenolic compounds such as oligomeric proanthocyanidins and trans-resveratrol. Phenolic compounds are important phytochemicals in grape because they possess many biological activities and health-promoting benefits [23]-[28].

The above findings led us to investigate the antimutagenic and DNA protective abilities of the grape extract VinOserae from Vitis vinifera applicable as a promising supplement with effective biological potential. In this work, in order to detect a protective effect of the VinOserae extract that prevents induction of oxidative DNA damages, a molecular biology method based on detection of changes in the topological state of the pBluescript II SK(-) plasmid was used. A different electrophoretic mobility of topological DNA forms was measured by the agarose gel electrophoresis. In the plasmid DNA test, the protective effect of the extract was determined on the basis of its capability to inhibit formation of DNA strand breaks in the plasmid DNA induced by hydrogen peroxide in the presence of transition metal ions [29]-[31].

The protective effect of the extract was independently evaluated with the Ames test using Salmonella typhimurium His ${ }^{-}$TA102 suitable to detect mutagenic effects of oxidative compounds. The evaluation of antimutagenic effects of the extract included detection of the ability to inhibit a mutagenic effect induced by hydrogen peroxide or tert-butyl hydroperoxide. These in vitro tests are useful to screen the antigenotoxic potential of plant extracts and to search potential bioactive compounds for possible aplication in food industry [32]-[35]. To the best of our knowledge this is the first report on DNA strand scission inhibitory and antimutagenic activities of the VinOserae extract.

\section{Material and Methods}

\subsection{Chemicals and Material}

The chemical reagents D-glucose-6-phosphate sodium salt, hydrogen peroxide, L-histidine, nicotinamide adenine dinucleotide phosphate and tert-butyl hydroperoxide were purchased from Sigma-Aldrich (St. Louis, USA), agarose and ethidium bromide from Serva Electrophoresis (Heidelberg, Germany). All reagents used were of analytical grade. The dry VinOserae extract was obtained from Favea, spol. s r.o. (Kopřivnice, Czech Republic). In the extract, phenolic compounds such as oligomeric proanthocyanidins and trans-resveratrol were identified.

\subsection{Bacterial Strain and Plasmid DNA}

Plasmid pBluescript II SK(-) DNA was isolated from the bacterial strain Escherichia coli TOP10. The isolation of plasmid pBluescript II SK(-) was carried out using columns Qiagen (QIAGEN Plasmid Mini Kit). The obtained plasmid DNA was dissolved in TE buffer (10 mM Tris, $1 \mathrm{mM}$ EDTA, $\mathrm{pH}$ 8.0) and stored at $-20^{\circ} \mathrm{C}$. Detection of mutagenic and antimutagenic activities of the plant extract was investigated using the auxotrophic bacterial strain Salmonella typhimurium His ${ }^{-}$TA102. For each experiment, a frozen stock of the tester strain culture (stored at $-80^{\circ} \mathrm{C}$ ) was grown overnight in Oxoid nutrient broth No. 2 using the procedure described in [34].

\subsection{Antimutagenicity Test}

The Ames test standard plate incorporation procedure was used for the assessment of antimutagenicity of the VinOserae extract. In order to detect the effect of the extract on tert-butyl hydroperoxide ( $t$-BHP) or hydrogen peroxide $\left(\mathrm{H}_{2} \mathrm{O}_{2}\right)$, an induced mutagenicity assay was employed using the Salmonella typhimurium His ${ }^{-}$TA102 strain sensitive to oxidant mutagens [32] [33]. A volume of $100 \mu \mathrm{l}$ of a bacterial culture (prepared as described in [34]), $50 \mu \mathrm{l}$ of the test sample (50 - $300 \mu \mathrm{g} /$ plate), $50 \mu \mathrm{l}$ of a mutagen ( $t$-BHP or $\mathrm{H}_{2} \mathrm{O}_{2}, 100 \mu \mathrm{g} / \mathrm{plate}$ ) and 500 $\mu \mathrm{l}$ of phosphate buffer $(0.1 \mathrm{mM}, \mathrm{pH}$ 7.4) were added to $2 \mathrm{ml}$ of the top agar that was supplemented with 0.05 $\mathrm{mM}$ histidine. The mixture was poured on minimal agar plates that were subsequently incubated at $37^{\circ} \mathrm{C}$ for $48 \mathrm{~h}$ and then histidine-revertant colonies on each plate were counted. The number of induced revertants was obtained by subtracting the number of spontaneous revertants from the number of revertants on the plates containing mutagen and antioxidant. The inhibition rate of mutagenicity (\%) was calculated as follows: percent inhibiton $(\%)=[1-$ (number of revertants on plates with oxidant and test compound - number of spontaneous rever- 
tants)/(number of revertants on plates with oxidant alone - number of spontaneous revertants)] $\times 100$ [35]. The results were analyzed with the statistical software "R".

\subsection{DNA Strand Scission Assay}

The plasmid pBluescript II SK(-) DNA was used to study the protective effect of the VinOserae extract on DNA damage induced by hydroxyl radicals. The method using plasmid DNA is based on different electrophoretic mobility of topological forms of the plasmid DNA. DNA strand breaks were measured by a conversion of supercoiled (Sc) form to open circular (Oc) and linear (Lin) forms of DNA [29] [30]. Plasmid DNA (0.5 $\mu \mathrm{g}$ ) was incubated with various concentrations of the extract (0.02 - $0.4 \mu \mathrm{g} / \mu \mathrm{l}), 0.1 \mathrm{M}$ Tris- $\mathrm{HCl}(\mathrm{pH} 8.0), 0.1 \mathrm{mM} \mathrm{FeSO}_{4}$, and $0.3 \% \mathrm{H}_{2} \mathrm{O}_{2}$ in an Eppendorf tube $\left(37^{\circ} \mathrm{C}, 30 \mathrm{~min}\right)$. The final volume of the mixture was $10 \mu \mathrm{l}$. DNA conformation changes were analyzed by agarose gel electrophoresis in $1 \mathrm{xTAE}$ buffer $(1 \%$ agarose, $7 \mathrm{~V} / \mathrm{cm}, 80 \mathrm{~min}$, room temperature). The gels were stained with ethidium bromide for $30 \mathrm{~min}$, followed by $30 \mathrm{~min}$ destaining in water. Photos of the gels were taken in UV light (transilluminator GeneGenius, SynGene, Cambridge, UK) and the bands were quantified using the software ImageJ [40].

\section{Results and Discussion}

Detection of the antimutagenic activity of the VinOserae extract was carried out using the Ames test with Salmonella typhimurium His ${ }^{-}$TA102. The antimutagenic effect of compounds can be evaluated on the basis of their ability to inhibit mutagen's mutagenicity [41]-[43]. The indicator strain Salmonella typhimurium His ${ }^{-}$TA102 is used for detection of mutagens inducing substitution mutations, often in the case of compounds with oxidative effect [32]-[44]. In order to measure an antimutagenic effect of the extract, both $\mathrm{H}_{2} \mathrm{O}_{2}$ and tert-butyl hydroperoxide ( $t$-BHP) were used at a concentration of $100 \mu$ g per plate to ensure a sufficient amount of revertants compared to the negative control [45] [46]. The VinOserae extract was tested at a range of $50-300 \mu$ g sample per plate. The results showed that a significant antimutagenic effect of the extract was detected with both oxidative mutagens used (Figure 1). The maximal decrease in the revertant numbers was found when the

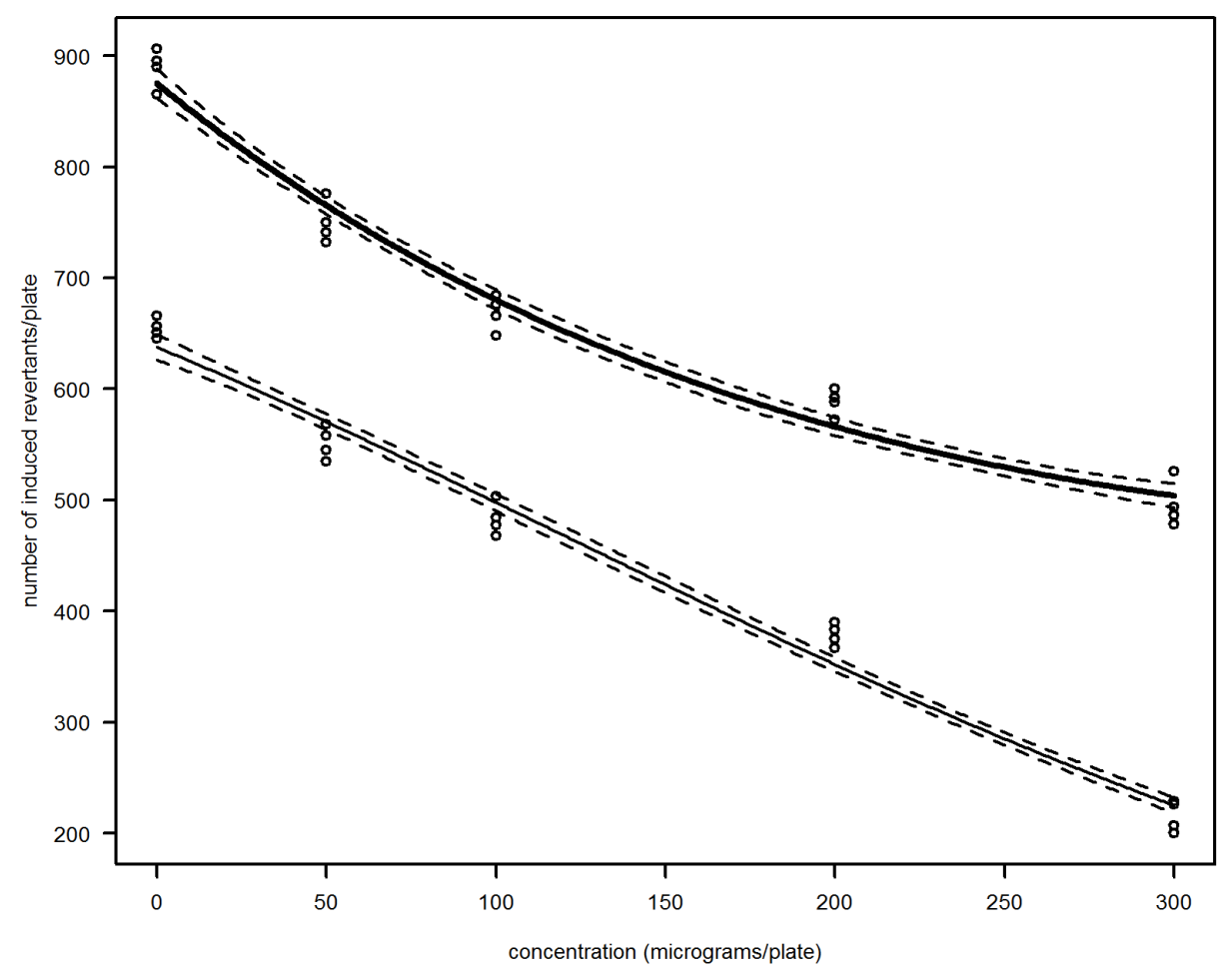

Figure 1. Antimutagenic activity of VinOserae extract in Ames test (without metabolic activation, strain TA102). Mutations were induced by $t$-BHP or $\mathrm{H}_{2} \mathrm{O}_{2}(100 \mu \mathrm{g} / \mathrm{plate})$. The amount of spontaneous revertants is subtracted. Line - $t$-BHP; line $-: \mathrm{H}_{2} \mathrm{O}_{2}$; line - - - -: standard error 
highest concentration of the extract was used with the two mutagens. The respective percentages of the inhibition of mutagenicity with $t$-BHP and $\mathrm{H}_{2} \mathrm{O}_{2}$ when a concentration of $300 \mu \mathrm{g}$ of the VinOserae extract per plate was used were 44.2 and $67.0 \%$ (Table 1).

Mutagenicity of the extract was examined as described in [34], we found no mutagenic effect irrespective of metabolic activation (not shown).

The ability of the VinOserae extract to inhibit oxidative damage of DNA was further investigated using the DNA strand scission assay where the protective effect of the extract was evaluated on the basis of its capability to inhibit formation of strand breaks in the plasmid pBluescript II SK(-) DNA. The principle of detection includes electrophoretic evaluation of changes in the topological state of the plasmid DNA. In its native form the double strand DNA of the plasmid pBluescript II SK(-) is in a compact supercoiled (Sc) conformation and has a relatively high electrophoretic mobility (Figure 2, lane 1). After a single strand break is introduced in the DNA, the supercoiled tertiary structure is impaired and results in the formation of an open circular (Oc) DNA form with a decreased electrophoretic mobility in the agarose gel. The linear (Lin) DNA form whose formation is induced by double strand breaks has a medium electrophoretic mobility between those of the supercoiled (Sc) and open circular (Oc) forms of plasmid DNA [47]-[49].

When the protective effect of the VinOserae extract was tested using plasmid DNA, the sample was not dissolved in dimethylsulfoxide but in ethanol. Some studies indicate that dimethylsulfoxide effectively inhibits formation of DNA strand breaks induced by the effect of hydroxyl radicals [50] [51]. Figure 2 shows how the extract affected the formation of DNA strand breaks induced by $\mathrm{H}_{2} \mathrm{O}_{2}$ in the presence of $\mathrm{FeSO}_{4}\left(\mathrm{Oc}_{\mathrm{c}}\right.$ and $\mathrm{Lin}$ forms of DNA, lane 3). The sample was tested in a concentration range of $0.02-0.4 \mu \mathrm{g} / \mu \mathrm{l}$. When the smallest dose of $0.02 \mu \mathrm{g} / \mu \mathrm{l}$ was applied, no inhibition of the formation of the open circular (Oc) and linear (Lin) DNA forms was observed (lane 4). The protective effect was observed when a dose of $0.05 \mu \mathrm{g} / \mu \mathrm{l}$ was used (lane 5). The strongest effect of inhibition of DNA strand breaks formation was found in lanes 7 - 10 when 0.15 - 0.4 $\mu \mathrm{g} / \mu \mathrm{l}$ sample was applied. The protective effect measured probably reflected the presence of these compounds in the extract since the ability to inhibit damage of plasmid DNA had been proven for many polyphenolic compounds [47] [52] [53].

Figure 3 shows results of quantitative measurement of the protective activity of the VinOserae extract capable to inhibit formation of DNA strand breaks in the plasmid pBluescript II SK(-). In the case of any extract concentration tested, a quantitative measurement of the content of supercoiled (Sc) DNA form was made using software ImageJ [40]. The value obtained for the supercoiled DNA form was related to that of the control. In a concentration range of $0.05-0.4 \mu \mathrm{g} / \mu \mathrm{l}$ used an increasing rate of the protective activity of the extract was found,

Table 1. Antimutagenic effect of VinOserae extract measured with Ames test using Salmonella typhimurium His ${ }^{-}$TA102 with $t$-BHP or $\mathrm{H}_{2} \mathrm{O}_{2}$ as the mutagenic compounds.

\begin{tabular}{ccccc}
\hline \multirow{2}{*}{ Mutagen $(100 \mu \mathrm{g} /$ plate $)$} & \multicolumn{4}{c}{ VinOserae extract $^{-}$} \\
\cline { 2 - 5 } & $50 \mu \mathrm{g} /$ plate $^{\mathrm{a}}$ & $100 \mu \mathrm{g} / \mathrm{plate}^{\mathrm{a}}$ & $200 \mu \mathrm{g} / \mathrm{plate}^{\mathrm{a}}$ & $300 \mu \mathrm{g} / \mathrm{plate}^{\mathrm{a}}$ \\
\hline tert-butyl hydroperoxide & 15.6 & 24.9 & 33.9 & 44.2 \\
hydrogen peroxide & 15.7 & 26.3 & 42.1 & 67.0 \\
\hline
\end{tabular}

${ }^{\mathrm{a}}$ The numbers represent a percentage (\%) of mutagenicity inhibition.

$\begin{array}{llllllllll}1 & 2 & 3 & 4 & 5 & 6 & 7 & 8 & 9 & 10\end{array}$

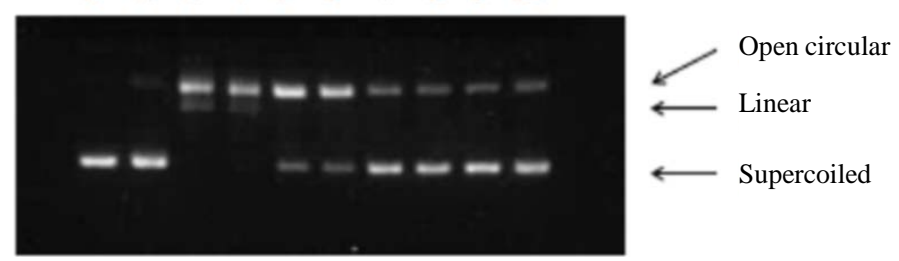

Figure 2. Electrophoretic pattern of pBluescript II SK(-) plasmid where DNA strand breaks were induced by $0.3 \% \mathrm{H}_{2} \mathrm{O}_{2}$ and $0.1 \mathrm{mM} \mathrm{FeSO}_{4}$ in the presence of VinOserae extract. Lane 1: control DNA; lane 2: $\mathrm{H}_{2} \mathrm{O}_{2}$ treatment alone; lane 3: $\mathrm{H}_{2} \mathrm{O}_{2}$ and $\mathrm{FeSO}_{4}$; lanes 4-10: $\mathrm{H}_{2} \mathrm{O}_{2}$ and $\mathrm{FeSO}_{4}$ in the presence of the extract (4: $0.02 \mu \mathrm{g} / \mu \mathrm{l} ; 5: 0.05 \mu \mathrm{g} / \mu \mathrm{l} ; 6: 0.1 \mu \mathrm{g} / \mu \mathrm{l} ; 7: 0.15 \mu \mathrm{g} / \mu \mathrm{l} ; 8$ : $0.2 \mu \mathrm{g} / \mu \mathrm{l} ;$ 9: $0.3 \mu \mathrm{g} / \mu \mathrm{l} ; 10: 0.4 \mu \mathrm{g} / \mu \mathrm{l})$. 


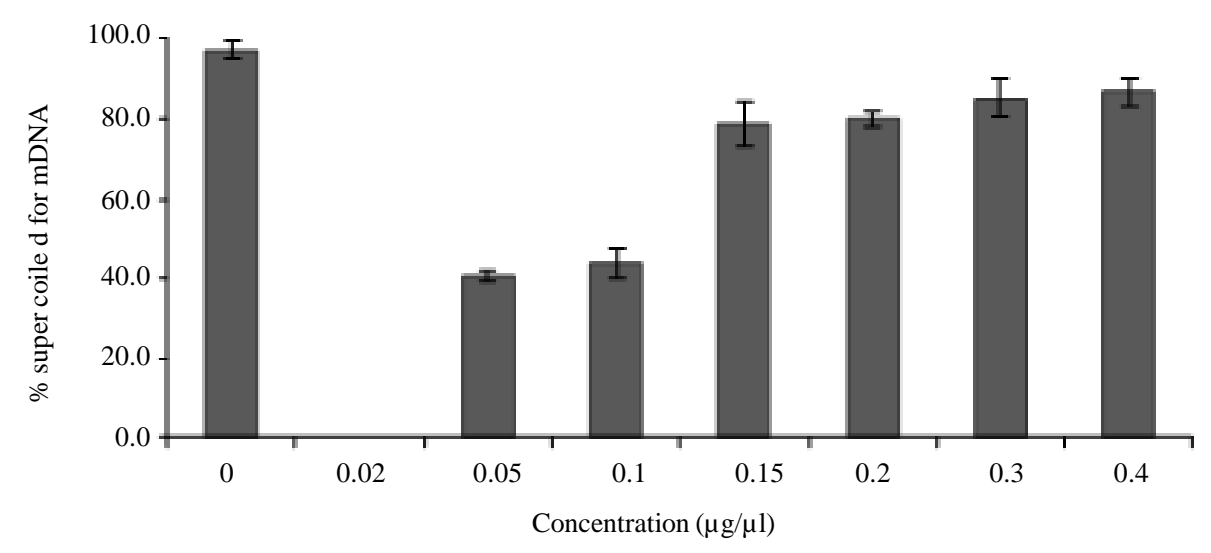

Figure 3. Analysis of supercoiled form of the plasmid pBluescript II SK(-) after DNA damage by ${ }^{\circ} \mathrm{OH}$ in the presence of VinOserae extract $(0.02-0.4 \mu \mathrm{g} / \mu \mathrm{l})$.

expressed by per cent value of the presence of supercoiled (Sc) form of the plasmid pBluescript II SK(-). The experiments showed no potential genotoxicity of the extract when applied to the plasmid pBluescript II SK(-).

\section{Conclusion}

Using DNA strand scission assay and the Ames test with Salmonella typhimurium His ${ }^{-}$, an ability of the VinOserae extract from Vitis vinifera grapes to efficiently inhibit oxidative damage of DNA was documented. No potential genotoxicity of the extract was detected. The results extend the knowledge of beneficial biological effects of compounds isolated from natural raw materials and bring further evidence of the VinOserae extract to be an interesting source of compounds with protective biological effect and applicability at food industry.

\section{Acknowledgements}

The work was supported by the project CZ.1.05/2.1.00/03.0100 (IET) financed by the Structural Funds of the Europe Union and project LO1208 of the National Feasibility Programme I of the Czech Republic and from Moravian-Silesian region government grant "Support of bilateral cooperation between Universities and research institutions in Moravian-Silesian region and in China: MSK(0095/RRC/2015)".

\section{References}

[1] Boubaker, J., Skandrani, I., Bouhlel, I., Ben Sghaier, M., Neffati, A., Ghedira, K. and Chekir-Ghedira, L. (2010) Mutagenic, Antimutagenic and Antioxidant Potency of Leaf Extracts from Nitraria retusa. Food and Chemical Toxicology, 48, 2283-2290. http://dx.doi.org/10.1016/j.fct.2010.05.061

[2] Carino-Cortés, R., Hernández-Ceruelos, A., Torres-Valencia, J.M., Gonzáles-Avila, M., Arriaga-Alba, M. and Madrigal-Bujaidar, E. (2007) Antimutagenicity of Stevia pilosa and Stevia eupatoria Evaluated with the Ames Test. Toxicology in Vitro, 21, 691-697. http://dx.doi.org/10.1016/j.tiv.2006.12.001

[3] Ho, K.Y., Tsai, C.C., Chen, C.P., Huang, J.S. and Lin, C.C. (2001) Antimicrobial Activity of Honokiol and Magnolol Isolated from Magnolia officinalis. Phytotherapy Research, 15, 139-141. http://dx.doi.org/10.1002/ptr.736

[4] Ramasamy, K. and Agarwal, R. (2008) Multitargeted Therapy of Cancer by Silymarin. Cancer Letters, 269, $352-362$. http://dx.doi.org/10.1016/j.canlet.2008.03.053

[5] Zhang, Y.M. and Rock, C.O. (2004) Evaluation of Epigallocatechin Gallate and Related Plant Polyphenols as Inhibitors of the FabG and FabI Reductases of Bacterial Type II Fatty-Acid Synthase. The Journal of Biological Chemistry, 279, 30994-31001. http://dx.doi.org/10.1074/jbc.M403697200

[6] Kris-Etherton, P.M., Hecker, K.D., Bonanome, A., Coval, S.M., Binkoski, A.E., Hilpert, K.F., Griel, A.E. and Etherton, T.D. (2002) Bioactive Compounds in Foods: Their Role in the Prevention of Cardiovascular Disease and Cancer. The American Journal of Medicine, 113, 71S-88S. http://dx.doi.org/10.1016/S0002-9343(01)00995-0

[7] Manach, C., Scalbert, A., Morand, C., Rémésy, C. and Jiménez, L. (2004) Polyphenols: Food Sources and Bioavailability. The American Journal of Clinical Nutrition, 79, 727-747.

[8] Scalbert, A. and Williamson, G. (2000) Dietary Intake and Bioavailability of Polyphenols. Journal of Nutrition, 
2073S-2085S.

[9] Verhagen, H., Rompelberg, C.J.M., Strube, M., Van Poppel, G. and Van Bladeren, P.J. (1997) Cancer Prevention by Dietary Constituents in Toxicological Perspective. Journal of Environmental Pathology, Toxicology and Oncology, 16, 343-360.

[10] Bors, W., Michel, C. and Stettmaier, K. (1997) Antioxidant Effects of Flavonoids. Biofactors, 6, 399-402. http://dx.doi.org/10.1002/biof.5520060405

[11] Edenharder, R. and Grünhage, D. (2003) Free Radical Scavenging Abilities of Flavonoids as Mechanism of Protection against Mutagenicity Induced by Tert-Butyl Hydroperoxide or Cumene Hydroperoxide in Salmonella typhimurium TA102. Mutation Research, 540, 1-18. http://dx.doi.org/10.1016/S1383-5718(03)00114-1

[12] Othman, A., Ismail, A., Ghani, N.A. and Adenan, I. (2007) Antioxidant Capacity and Phenolic Content of Cocoa Beans. Food Chemistry, 100, 1523-1530. http://dx.doi.org/10.1016/j.foodchem.2005.12.021

[13] Seyoum, A., Asres, K. and El-Fiky, F.K. (2006) Structure-Radical Scavenging Activity Relationships of Flavonoids. Phytochemistry, 67, 2058-2070.

[14] Van Acker, S.A.B.E., Van Balen, G.P., Van den Berg, D.J., Bast, A. and Van der Vijgh, W.J.F. (1998) Influence of Iron Chelation on the Antioxidant Activity of Flavonoids. Biochemical Pharmacology, 56, 935-943. http://dx.doi.org/10.1016/S0006-2952(98)00102-6

[15] Fernandes, F., Ramalhosa, E., Pires, P., Verdial, J., Valentao, P., Andrade, P., Bento, A. and Pereira, J.A. (2013) Vitis vinifera Leaves towards Bioactivity. Industrial Crops and Products, 43, 434-440. http://dx.doi.org/10.1016/j.indcrop.2012.07.031

[16] Orhan, N., Aslan, M., Deliorman Orhan, D., Ergun, F. and Yesilada, E. (2006) In-Vivo Assessment of Antidiabetic and Antioxidant Activities of Grapevine Leaves (Vitis vinifera) in Diabetic Rats. Journal of Ethnopharmacology, 108, 280-286. http://dx.doi.org/10.1016/j.jep.2006.05.010

[17] Bozan, B., Tosun, G. and Özcan, D. (2008) Study of Polyphenol Content in the Seeds of Red Grape (Vitis vinifera L.) Varieties Cultivated in Turkey and Their Antiradical Activity. Food Chemistry, 109, 426-430. http://dx.doi.org/10.1016/j.foodchem.2007.12.056

[18] Dopico-Garcia, M.S., Fique, A., Guerra, L., Afonso, J.M., Pereira, O., Valentao, P., Andrade, P.B. and Seabra, R.M. (2008) Principal Components of Phenolics to Characterize Red Vinho Verde Grapes: Anthocyanins or Non-Coloured Compounds? Talanta, 75, 1190-1202. http://dx.doi.org/10.1016/j.talanta.2008.01.012

[19] Liang, Z., Owens, C.L., Zhong, G.-Y. and Cheng, L. (2011) Polyphenolic Profiles Detected in the Ripe Berries of Vitis vinifera Germplasm. Food Chemistry, 129, 940-950. http://dx.doi.org/10.1016/j.foodchem.2011.05.050

[20] Novaka, I., Janeiroa, P., Serugab, M. and Oliveira-Brett, A.M. (2008) Ultrasound Extracted Flavonoids from Four Varieties of Portuguese Red Grape Skins Determined by Reverse-Phase High-Performance Liquid Chromatography with Electrochemical Detection. Analytica Chimica Acta, 630, 107-115. http://dx.doi.org/10.1016/j.aca.2008.10.002

[21] Perestrelo, R., Lu, Y., Santos, S.A.O., Silvestre, A.J.D., Neto, C.P., Camara, J.S. and Rocha, S.M. (2012) Phenolic Profile of Sercial and Tinta Negra Vitis vinifera L. Grape Skins by HPLC-DAD-ESI-MSn. Novel Phenolic Compounds in Vitis vinifera L. Grape. Food Chemistry, 135, 94-104. http://dx.doi.org/10.1016/j.foodchem.2012.04.102

[22] Spacil, Z., Novakova, L. and Solich, P. (2008) Analysis of Phenolic Compounds by High Performance Liquid Chromatography and Ultra Performance Liquid Chromatography. Talanta, 76, 189-199. http://dx.doi.org/10.1016/j.talanta.2008.02.021

[23] Xia, E.-Q., Deng, G.-F., Guo, Y.-J. and Li, H.-B. (2010) Biological Activities of Polyphenols from Grapes. International Journal of Molecular Sciences, 11, 622-646. http://dx.doi.org/10.3390/ijms11020622

[24] Iacopini, P., Baldi, M., Storchi, P. and Sebastiani, L. (2008) Catechin, Epicatechin, Quercetin, Rutin and Resveratrol in Red Grape: Content, in Vitro Antioxidant Activity and Interactions. Journal of Food Composition and Analysis, 21, 589-598. http://dx.doi.org/10.1016/j.jfca.2008.03.011

[25] Shrikhande, A.J. (2000) Wine By-Products with Health Benefits. Food Research International, 33, 469-474. http://dx.doi.org/10.1016/S0963-9969(00)00071-5

[26] Silva, R.C., Rigaud, J., Cheynier, V. and Chemina, A. (1991) Procyanidin Dimers and Trimers from Grape Seeds. Phytochemistry, 30, 1259-1264. http://dx.doi.org/10.1016/S0031-9422(00)95213-0

[27] Thiruchenduran, M., Vijayan, N.A., Sawaminathan, J.K. and Devaraj, S.N. (2011) Protective Effect of Grape Seed Proanthocyanidins against Cholesterol Cholic Acid Diet-Induced Hypercholesterolemia in Rats. Cardiovasc. Pathology, 20, 361-368. http://dx.doi.org/10.1016/j.carpath.2010.09.002

[28] Wada, M., Kido, H., Ohyama, K., Ichibangas, T., Kishikaw, N., Ohba, Y., Nakashima, M.N., Kurod, N. and Nakashima, K. (2007) Chemiluminescent Screening of Quenching Effects of Natural Colorants against Reactive Oxygen Species: Evaluation of Grape Seed, Monascus, Gardenia and Red Radish Extracts as Multi-Functional Food Additives. 
Food Chemistry, 101, 980-986. http://dx.doi.org/10.1016/j.foodchem.2006.02.050

[29] Cao, W., Chen, W.J., Suo, Z.R. and Yao, Y.P. (2008) Protective Effects of Ethanolic Extracts of Buckwheat Groats on DNA Damage Caused by Hydroxyl Radicals. Food Research International, 41, 924-929. http://dx.doi.org/10.1016/j.foodres.2007.10.014

[30] Russo, A., Acquaviva, R., Campisi, A., Sorrenti, V., Di Giacomo, C., Virgata, G., Barcellona, M.L and Vanella, A. (2000) Bioflavonoids as Antiradicals, Antioxidants and DNA Cleavage Protectors. Cell Biology and Toxicology, 16, 91-98. http://dx.doi.org/10.1023/A:1007685909018

[31] Rybkova, Z. and Malachova K. (2011) The Use of Plasmid pBluescript for Detection of Antioxidative Activity of Plant Phenolics. Chemicke Listy, 105, 129-132.

[32] Levin, D.E., Hollstein, M., Christman, M.F., Schwiers, E.A. and Ames, B.N. (1982) A New Salmonella Tester Strain (TA102) with A-T Base Pairs at the Site of Mutation Detects Oxidative Mutagens. Proceedings of the National Academy of Sciences of the United States of America, 79, 7445-7449. http://dx.doi.org/10.1073/pnas.79.23.7445

[33] Levin, D.E., Hollstein, M., Christman, M.F. and Ames, B.N. (1984) Detection of Oxidative Mutagens with a New Salmonella Tester strain (TA102). Methods in Enzymology, 105, 249-254. http://dx.doi.org/10.1016/S0076-6879(84)05032-1

[34] Mortelmans, K. and Zeiger, E. (2000) The Ames Salmonella/Microsome Mutagenicity Assay. Mutation Research, 455, 29-60. http://dx.doi.org/10.1016/S0027-5107(00)00064-6

[35] Stagos, D., Kazantzoglou, G., Theofanidou, D., Kakalopoulou, G., Magiatis, P., Mitaku, S. and Kouretas, D. (2006) Activity of Grape Extracts from Greek Varieties of Vitis vinifera against Mutagenicity Induced by Bleomycin and Hydrogen Peroxide in Salmonella typhimurium Strain TA102. Mutation Research, 609, 165-175. http://dx.doi.org/10.1016/j.mrgentox.2006.06.032

[36] Ames, B.J., McCann, J. and Yamasaki, E. (1975) Methods for Detecting Carcinogens and Mutagens with the Salmonella/Mammalian-Microsome Mutagenicity Test. Mutation Research, 31, 347-364. http://dx.doi.org/10.1016/0165-1161(75)90046-1

[37] Malachová, K., Pavlícková, Z., Novotný, C., Svobodová, K., Lednická, D. and Musílková, E. (2006) Reduction in the Mutagenicity of Synthetic Dyes by Successive Treatment with Activated Sludge and the Ligninolytic Fungus, Irpex lacteus. Environmental and Molecular Mutagenesis, 47, 533-540. http://dx.doi.org/10.1002/em.20224

[38] Broekhoven, L.H. and Nestmann, E.R. (1991) Statistical Analysis of the Salmonella Mutagenicity Assay. In: Krewski, D. and Franklin, C, Eds., Statistics in Toxicology, Gordon \& Breach, Amsterdam, 28-34.

[39] Margolin, B.H., Kim, B.S. and Risko, K.J. (1989) The Ames Salmonella/Microsome Mutagenicity Assay: Issues of Inference and Validation. Journal of the American Statistical Association, 84, 651-661. http://dx.doi.org/10.2307/2289645

[40] Abràmoff, M.D., Magalhães, P.J. and Ram, S.J. (2004) Image Processing with ImageJ. Biophotonics International, 11, 36-42.

[41] Brindzová, L., Mikulášová, M., Takácsová, M., Mošovská, S. and Opattová, A. (2009) Evaluation of the Mutagenicity and Antimutagenicity of Extracts from Oat, Buckwheat and Wheat Bran in the Salmonella/Microsome Assay. Journal of Food Composition and Analysis, 22, 87-90. http://dx.doi.org/10.1016/j.jfca.2008.07.009

[42] Horn, R.C. and Vargas, V.M.F. (2008) Mutagenicity and Antimutagenicity of Teas Used in Popular Medicine in the Salmonella/Microsome Assay. Toxicology in Vitro, 22, 1043-1049. http://dx.doi.org/10.1016/j.tiv.2007.12.014

[43] Makena, P.S. and Chung, K.T. (2007) Effects of Various Plant Polyphenols on Bladder Carcinogen Benzidine-Induced Mutagenicity. Food and Chemical Toxicology, 45, 1899-1909. http://dx.doi.org/10.1016/j.fct.2007.04.007

[44] Dillon, D., Combes, R. and Zeiger, E. (1998) The Effectiveness of Salmonella Strains TA100, TA102 and TA104 for Detecting Mutagenicity of Some Aldehydes and Peroxides. Mutagenesis, 13, 19-26. http://dx.doi.org/10.1093/mutage/13.1.19

[45] Ferrer, M., Sánchez-Lamar, A., Fuentes, J.L., Barbé, J. and Llagostera, M. (2002) Antimutagenic Mechanisms of Phyllanthus orbicularis When Hydrogen Peroxide Is Tested Using Salmonella Assay. Mutation Research, 517, 251-254. http://dx.doi.org/10.1016/S1383-5718(02)00064-5

[46] Grey, C.E. and Adlercreutz, P. (2003) Ability of Antioxidants to Prevent Oxidative Mutations in Salmonella typhimurium TA102. Mutation Research, 527, 27-36. http://dx.doi.org/10.1016/S0027-5107(03)00054-X

[47] Lee, E.J. and Jang, H.D. (2004) Antioxidant activity and protective effect on DNA strand scission of Rooibos tea (Aspalathus linearis). Biofactors, 21, 285-292. http://dx.doi.org/10.1002/biof.552210156

[48] Rahman, A., Fazal, F., Greensill, J., Ainley, K., Parish, J.H. and Hadi, S.M. (1992) Strand Scission in DNA Induced by Dietary Flavonoids: Role of $\mathrm{Cu}(\mathrm{I})$ and Oxygen Free Radicals and Biological Consequences of Scission. Molecular and Cellular Biochemistry, 111, 3-9. http://dx.doi.org/10.1007/BF00229567 
[49] Yoshino, M., Haneda, M., Naruse, M. and Murakami, K. (1999) Prooxidant Activity of Flavonoids: Copper-Dependent Strand Breaks and the Formation of 8-Hydroxy-2'-Deoxyguanosine in DNA. Molecular Genetics and Metabolism, 68, 468-472. http://dx.doi.org/10.1006/mgme.1999.2901

[50] Kong, D.M., Wang, J., Zhu, L.N., Jin, Y.W., Li, X.Z., Shen, H.X. and Mi, H.F. (2008) Oxidative DNA Cleavage by Schiff Base Tetraazamacrocyclic Oxamido Nickel(II) Complexes. Journal of Inorganic Biochemistry, 102, 824-832. http://dx.doi.org/10.1016/j.jinorgbio.2007.12.002

[51] Liu, X., Lu, J. and Liu, S. (1999) Synergistic Induction of Hydroxyl Radical-Induced DNA Single-Strand Breaks by Chromium(VI) Compound and Cigarette Smoke Solution. Mutation Research, 440, 109-117. http://dx.doi.org/10.1016/S1383-5718(99)00015-7

[52] Khan, N.S., Ahmad, A. and Hadi, S.M. (2000) Anti-Oxidant, Pro-Oxidant Properties of Tannic Acid and Its Binding to DNA. Chemico-Biological Interactions, 125, 177-189. http://dx.doi.org/10.1016/S0009-2797(00)00143-5

[53] Ueda, J., Saito, N., Shimazu, Y. and Ozawa, T. (1996) A Comparison of Scavenging Abilities of Antioxidants against Hydroxyl Radicals. Archives of Biochemistry and Biophysics, 333, 377-384. http://dx.doi.org/10.1006/abbi.1996.0404 